\title{
Bank Selection Criteria in the Saudi Community Empirical Study of Saudi Banks' Customers in Tabuk City
}

\author{
Bakhita Hamdow Gad Elkreem Braima \\ University of Tabuk/ faculty of business administration
}

\begin{abstract}
The study aims to investigate the determinant factors of bank choice among Saudi community; to rank these determining factors according of the customer's priority; and to examine whether Saudi banks 'customers will be a homogeneous group concerning the way they select a bank or not.it follows a descriptive survey research design, quantitative research approach is adopted through the semi-open structure questionnaire. Total of 178 respondents from different banks (full fledge Islamic, conventional and Islamic window banks) as of a single point in time in the form of quantitative measures. Exploratory Factor Analysis is employed to rank factors effect bank choice criteria among Saudi people. Results of factor analysis reveal that ranks of factors affect customer decision in selecting a bank service based on mean, are satisfaction(mean $=4.05$ ) , service quality (mean=3.74), Islamic value (mean $=3.7$ ), service cost(mean=3.5),financial intermediate (mean $=3.39$ ). Moreover it discovers that Customers in Saudi banks are homogeneous. Lessons to be learned from the study result, Saudi banks should focus on service quality,; note that Saudi Arabia is one of transfers' countries, and Islamic banks should be emphasizing on customers 'trust about services consistent with sharia'h provision.
\end{abstract}

Keywords: bank choice, factor analysis, Islamic value, service quality, customer behavior
*Correspondence to Author:

Bakhita Hamdow Gad Elkreem Braima

University of Tabuk/ faculty of business administration

How to cite this article:

Bakhita Hamdow Gad Elkreem Braima. Bank Selection Criteria in the Saudi Community Empirical Study of Saudi Banks' Customers in Tabuk City. Global journal of Economics and Business Administration, 2018, 3: 15.

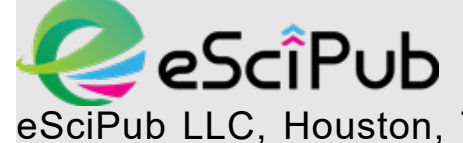

Website: http://escipub.com/ 


\section{Introduction:}

Understanding customers' banks selection criteria has been argued to be helpful to banks in identifying the appropriate marketing strategies needed to attract new customers and retain existing ones. In this light this paper investigates the various factors and analyzes the impact of these factors in developing customer intention for bank selection in Saudi Arabia with special reference Tabuk city, in 2017m. (1439 h)

This study tries to answer the question: what is most important factor that affects banks selection criteria? And whether any difference is available between Islamic banks 'customer and their counterpart conventional 'customers in developing customer intention for bank selection.

The study aims to investigate the determinant factors of bank choice among Saudi community; to rank these determining factors in order of customer's priority; and to examine whether Saudi banks 'customers will be a homogeneous group concerning the way they select a bank or not.

The study consists of six parts which include: introduction; background and literature review; data analysis; result discussion; conclusion and last section is references \& appendixes

\section{Theoretical background:}

\section{The bank selection process:}

In banking system today, commercial banks are not only buying and selling money, but also aim to provide appropriate financial services to customers (1). Actually, customer-oriented activity refers to marketing which require that banks have a comprehensive understanding of customers' attitudes, perceptions and behavior (2)

In addition, banks need to instantly change their marketing policies and strategies to adapt constant environmental changes as well as match the demand of complex marketplace, in order to understand choice or selection behavior of individual customer and make appropriate marketing strategies (1).

According to (1) the world could be divided into two types of countries regarding the difference of commercial banking industry: cheque-book countries and transfers countries (figure1). Canada, the USA and the UK are typically cheque-book countries where cheques account is frequently used, while Japan, Finland, Sweden and Germany are typical transfers' country where people use bank transfer as cashless payments.

In addition, many researches were conducted in Australia (2), Finland (1) and Hong Kong (3) and showed that a commercial banks' marketing orientation is determined by three market segments (figure1). Firstly, "taskoriented bank customers" are considered as a consumer group who emphasizes on the bank's professionalism. Secondly, "security-oriented customers" appear in the requirement for a bank with a good reputation and high (2). Thirdly, "interaction-oriented customers" usually prefer friendly and confidentiality service of the bank (2) Thus, depend on the classification of customers, banks can be able to identify which types of market segment they belong to.

According to specific market segment, marketing strategies would be clearly developed in order to satisfy customers. For example, interaction-oriented customers significantly value the banking service quality, such as the variety of services, the attitude of bank employees and speed of services. Based on their needs, bank managers could train employees to be more polite and efficient in providing services to customers.

Moreover, customers are divided into frequency usage and infrequency usage, based on the frequency of banking services been used. All the processes are leading to the final result--satisfaction. Customers will be loyal if they satisfy with the banking services. On the contrary, they would switch bank when dissatisfaction generates (2). 
Figure 1: The bank selection process:

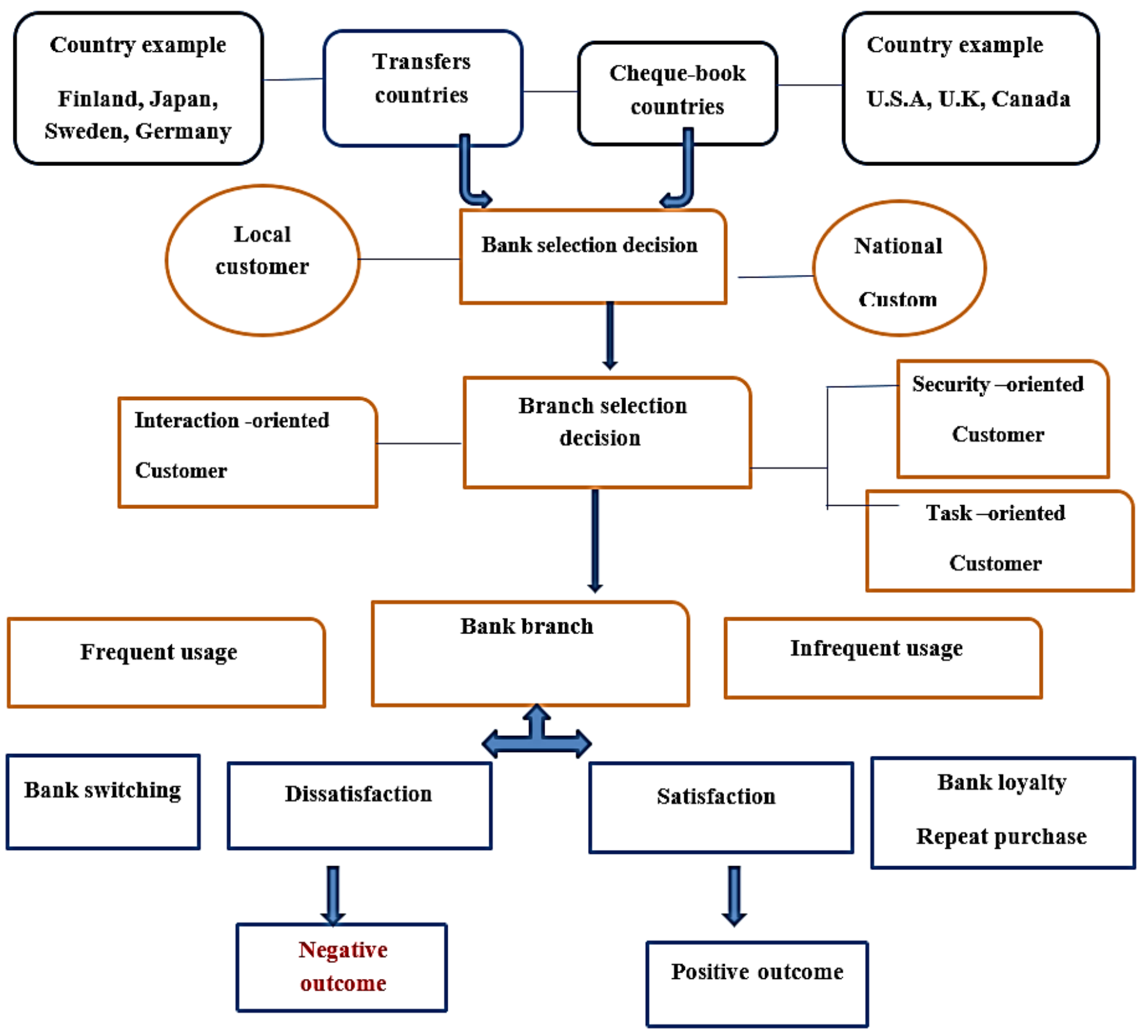

Source : Kayand Holistus,1995,pp.12(1)

Combining the framework which was developed by Kaynak and Holstius (1995), the research findings would be analyzed for two purposes. On one hand, Saudi community' bank selection process could be more deeply understand by researcher. On the other hand, it would be beneficial for researcher to analyze the market segment of Saudi people even they are national (their nationality Saudi) or international (nonSaudi (Moqeem). This may help banks to develop appropriate marketing strategies to international students.
As banking is considered a service industry which requires developing individually customized service solutions for customers, customer service and satisfaction have been the main areas of academic research (4). Many researchers have recognized that developing valid measures of service quality is necessary. For example, Frost and Kumar (2000) (5) have developed internal service quality model. The P-C-P attributes model is created by Philip and Hazlett (1997)(6). The Internet banking model is developed by Broderick and Vachirapornpuk (2002)(7) The development of service theories 
has led to the rise of service quality development in the past decades. Nevertheless, one of the most critical assessment tools of service quality is SERVQUAL which originally developed by Parasuraman et al. (1985) (8) he suggested that service quality is a comparison between customer expectation of service and their evaluation of the service performance. In other word, delivering good quality of service require conforming customers expectation consistently. At the beginning, SERVQUAL was originally measured on 10 dimensions including 34 items of service. But some of the items are found overlap in later researches, so the model has been purified in to five key factors: "reliability", "tangibles", "empathy", "assurance" and "responsiveness" (9)

\section{The definition is described as follow:}

> Reliability: Ability to perform and complete promised service and accuracy within the given set of requirements;

> Tangibles: Physical facilities, equipment and appearance of personnel;

> Responsiveness: The Company has the willingness to provide its customers with prompt service;

> Assurance: Knowledge and courtesy of employees who have the ability to inspire trust and confidence

> Empathy: Providing care and giving individualized attention to customers in order to satisfy the customers;

\section{Literature review:}

\section{Customer Satisfaction:}

The most popular view of customer satisfaction in academia is that customer satisfaction is the judgment borne out of the comparison of prepurchase expectations with post purchase evaluation of the product or service experience (8) ,(16) Customer satisfaction can result from any dimension (whether or not it's quality related) and its judgments may arise from nonquality issues (e.g. needs, equity, and perceptions of 'fairness') and require experience with the service provider $16 ;(10)$ demonstrated that safety of fund and availability of technology based services, quick service ,minimum waiting time, low/reasonable service-charge and pleasing manner of staff are major factors in a bank selection in Nigeria.

\section{Personal Factors:}

When we consider personal factors, friendly/pleasing manner of staff is the major factor in a bank selection by the sampled customers of the bank (11)and (12). According to the findings of (13) , the second most common reason for customers to leave retail banks in Mekelle city was due to staff attitude. In contrast, (14) and (15) revealed that Employee's attitudes were found to be insignificant factors.;(16) they demonstrated that friendly or pleasing manner of staff, ATM service, bank speed, service quality, external bank appearance and internal sitting arrangement, secured feeling, proximity to home or work place, availability of several branches and long operating hours were significant factors; whereas others' recommendations, number of counter windows, safety of funds, good reception at the bank and low service charge were insignificant factors for bank selection decision.

\section{Service Quality:}

(16), stated that delivering quality services and products to customers had significant positive influence for success and survival of today's competitive banking environment; (10) By using a survey of households The Determinants of Bank Selection Choices by Customers: Recent and Extensive Evidence from Nigeria. His study revealed that the safety of funds and the availability of technology-based service(s) are the major reasons for customers' choice of banks.

(17) Their research had tried to find out exact determinants affecting customer's choice of bank using mortgage products in context of Pakistan. They had demonstrated that choice of customers for the mortgage product depends 
on quality of services, cost of mortgage product, confidence level of customers build by the bank and convenience of the customers.; (18) They had studied quality of services and range of services as determinants of customer choice of banking in Malaysia, their results showed that both quality and range of services emerged as significant factors in determining the banking choice. ;(19), Their results showed that service is the most influential of all the six determinant-factors (which include Proximity, attractiveness, referrals, marketing and price followed suit, and quality of services) for the choice of commercial banks

\section{Islamic value perception \&understanding:}

(20) , their study aimed to understand the key motivations for Islamic bank patronage among Muslims using in-depth interviews and nonparticipant observation in Malaysian community . The theoretical framework of this study was customer-oriented. They have found that: shariah-adherent behaviour among Muslims in Terengganu (city in Malaysia) has not reached the ideal level although these customers understand the basic concepts of Islamic banking and are aware of the importance of dealing only with such banks. Accordingly they recommended that efforts on the appreciation of Islamic values require further emphasis, also they demonstrated that: influence of religion on the selection of Islamic bank among Muslims in Terengganu. Accordingly they recommend that marketing activities by Islamic banks should consistently comply with the shariah principles.

Kabiru\&lbrhim(2014) (21), he investigated the relationships among the variables - Perception, Awareness, and Understanding of Muslim's Account holder's in conventional bank to purchase Islamic bank products he demonstrated that Perception, Awareness and Understanding are positively associated with Muslim account holders in conventional banks toward Islamic banking products. then he recommended that the Islamic banking industry should focus on the people's understanding of
Shariah position on business transactions, concept of profit and loss sharing practice, benefit of Islamic banking products, good understanding of Islamic banking theory and practice that would have impact on customer decision.

Ahmad and Haron (2002) conducted their research based upon a sample taken from Malaysian Islamic bank customers; they have reported that the majority of Islamic bank customers emphasized religious as well as other factors like cost/benefit, service delivery, reputation and location in patronizing Islamic banks

According to Dar (2000)(23) it is very important to give customer awareness and education for the development of Islamic Banking in the developed countries like UK.

Salman Masood (2014)(24) they investigated customer awareness and perception towards the Islamic Banking products and how this perception and awareness can be raised for the greater success of Islamic banking products. Their results showed that customers use only the current and saving accounts; they do not use different modes of financing because of less awareness about the products and financing modes of Islamic banks. Even bankers by themselves not have full awareness of Islamic banking products and services.

Adi Zakaria Afiff(June 2009)(25) they aimed to test the addition of a spiritual dimension in the formation of customer value, in addition to the functional, social and emotional dimension of customer value that has already been empirically tested in previous studies, among customers who own saving products at Islamic banks in Indonesia. The study also investigated the relationship between customer value and customer satisfaction, and the relationship between customer satisfaction and customer behavioral intentions among these Islamic banks customers. Their results showed that spiritual dimension is significantly related to the customer value together with all 3 other dimensions (functional, social and emotional) of 
customer value. Also, they demonstrated that customer's values positively influence customer satisfaction, and customer satisfactions positively influence customer behavior intentions.

Muryani Arsli (2014)(26) hey stated that the behavior of consumers in Islamic banks is dominated by customer choice of Islamic banking cause a sense of satisfaction with quality of services such as efficient services, the speed of the transaction, service quality, convenience, reputation and image of the Islamic but not concerned with Shariah, whereas Islamic banking is based on the principles, rules and Islamic law (Malaysia).

\section{Profitability:}

Rahmatina A. Kasri (27), their empirical study investigated the factors affecting saving in the Islamic banks in Indonesia.By employing the Vector Autoregressive and its associated Impulse Response Function analysis for all Islamic banks in Indonesia from March 2000 to August 2007, the study analyzes the importance of real rate of return on Islamic deposit, interest rate on conventional deposit, real income. their results showed that higher Islamic deposit is significantly correlated with higher rate of return and lower interest rate; Furthermore, the study finds the existence of displaced commercial risk between the Islamic and conventional banks, such that the Islamic banks' depositors transfer their funds to the conventional banks when the rate of return provided by the Islamic banks is significantly lower than the interest rate of its counterpart.

\section{Convenience factor:}

Convenience factors include location convenience, operating of bank, and availability of transport to reach the bank, availability of bank ATM at multiple locations, location of ATM's, multiple branches of the bank, availability of parking space near the bank (28)

(28), his result showed that out of six factors five factors which included., technology factors, social influence, service quality factors, bank image factors, and financial factors have significant impact on bank selection intention while convenience factor has insignificant impact.

(29) he investigated the influence of bank "characteristics on service choosing, he has estimated the probability of usage of more than 1 service. Then he stated that: as for bank characteristics, influence of bank's reliability, proximity to work or home, number of clients, speed of development, and bank's honesty matter for at least one service.

\section{Summary of theoretical discussion:}

\section{The determinants of the bank selection decision:}

Basing on SERVQUAL theories and other previous similar researches, the researcher concludes six factors that are considered key variables affecting customer' bank selection in previous researches and develop a model as a theoretical framework of her research.

\section{Theoretical framework of research}

Depending on six factors and service quality background the researcher selects from previous researches, five aspects are concluded

Figure (2): "financial intermediate ", "cost", "satisfaction" and "service quality," And Islamic value "In order to investigate the key factors that affect the preference of Saudi banks' customers, and what are Items that can be consider as components of each factor

\section{Research design:}

\section{Methodology:}

This study employed a descriptive survey research design since the objective is identifying the factors that affect customers' bank selection criteria, in order to rank that factors according to their importance, and if there is any difference between customers groups in that factors so that it uses a questionnaire survey data collection instrument of bank customers, it involves respondents from different banks as of a single point in time in the form of quantitative measures. The GJEBA: http://escipub.com/global-journal-of-economics-and-business-administration/ 
questionnaire was designed to enable rating the relative importance of five factors attributes when choosing banks. They were measured on a five-point Likert-type scale of importance ranging from ( $5=$ very most important) to ( $1=$ not important at all). The questions of the questionnaire are divided into two parts; The first section of the questionnaire asks respondents' personal information, which includes gender, age, education level, religious , nationality, job type ,whether respondent has opened bank account or not ; and the second section of questionnaire asks respondents about the determinant factors of their bank selection, which include service quality, customer satisfactions, Islamic value, cost of services ,financial intermediate .

\section{Table (1) Summary of theoretical discussion}

\begin{tabular}{|c|c|c|}
\hline Label & aspects & items \\
\hline 1 & satisfaction & $\begin{array}{l}\text { Judgment from a comparison of pre-purchase expectations with post purchase } \\
\text { evaluation of the banks 'service } \\
\text { require experience with the service provider }\end{array}$ \\
\hline 2 & $\begin{array}{l}\text { Personal } \\
\text { Factors }\end{array}$ & $\begin{array}{l}\text { friendly/pleasing manner of staff } \\
\text { Attitude of staff }\end{array}$ \\
\hline 3 & service quality & $\begin{array}{l}\text { reliability(Accuracy in account management, } \\
\text {;tangibles(Parking facilities, appearance of staff and bank building) } \\
\text { responsiveness(Speed of service) } \\
\text { assurance( Safety of funds) } \\
\text { empathy (Friendliness and helpfulness of personnel, Giving personal attention to } \\
\text { customers) }\end{array}$ \\
\hline 4 & $\begin{array}{l}\text { Islamic value } \\
\text { perception } \\
\text { \&understanding }\end{array}$ & $\begin{array}{l}\text { Awareness of Islamic banking products \&services , and its compliance of } \\
\text { shareiah provision by employees } \\
\text { Customer ensure a bank provides them banking and financing services } \\
\text { completely free from any shareiah constrains }\end{array}$ \\
\hline 5 & profitability & High Rate of return on customer deposits \\
\hline 6 & convenience & $\begin{array}{l}\text { location convenience, operating of bank, and availability of transport to reach the bank, } \\
\text { availability of bank ATM at multiple locations, location of ATM's, multiple branches of the } \\
\text { bank, availability of parking space near the bank. }\end{array}$ \\
\hline
\end{tabular}

\section{Data Collection:}

For the purpose of investigating factors that affect the preference of Saudi community toward type of bank services, the study is adopted quantitative research approach through the semi-open structure questionnaire. The questionnaires are distributed not only to Saudi people, but also to non-Saudi people (Mqeem). As planned, the time from distribution of the questionnaire to the end of receiving the answers is two weeks. Since there is no previous research concerning the customers' banking selection criteria in Saudi Arabia it required an exploratory study to identify some important variables which may not be known carefully.

In accordance with the non-probabilistic convenience sampling, a sample size of 200 respondents is selected. But only 178 questionnaires are received back. 
Figure (2) Theoretical framework of research

\section{Independent factors}

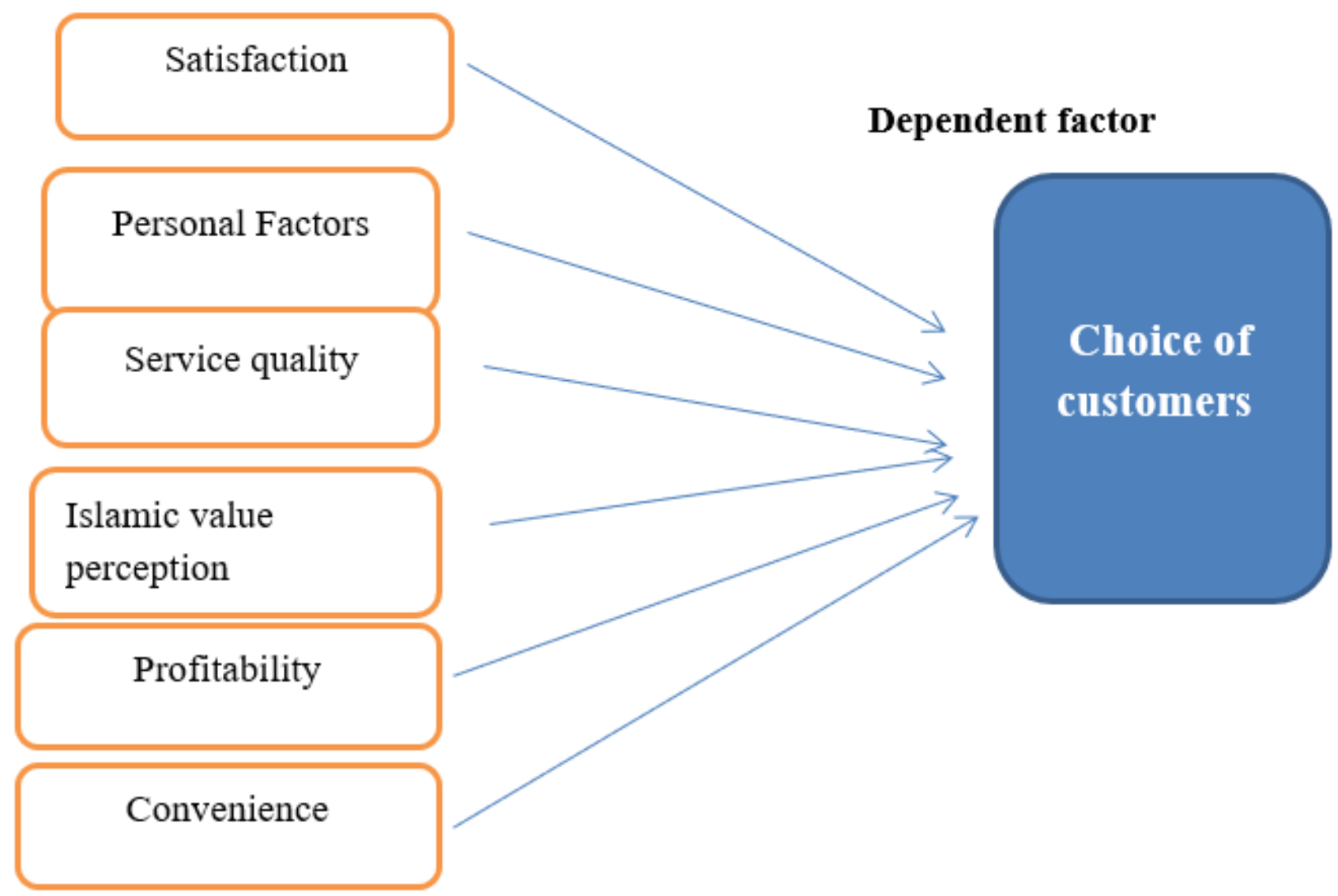

\section{Validity:}

Before the survey was conducted, in order to determine the validity of the questionnaire and to Improve, ten questionnaires was distributed to research experts' reviewers. Where their grades two Professor majoring in finance, one Professor in business administration, one Professor in statistics (total $=4$ Professors) and 2 associate professors in business administration plus one participant in statistics (total $=3$. participant) and two Assistant Professor in economics plus one assistant in finance (total $=3$. Assistant). The total number of arbitrators $=10$. So a researcher asked them if there is any wrong question or misunderstanding, besides if the arbitrators have any comments on these questionnaires, the suggestions were welcome. Then Questionnaires were modified according to the comments and suggestions from arbitrators and distributed through Email and face to face contact.

\section{Reliability:}

According to Cooper and Schindler (2003) (30), data reliability is concerned with a measurement of Consistency. In order to check the reliability of the data, researcher adapts one of the most commonly Indicators of internal consistency: Cronbach's alpha test in the SPSS 19. Pallant (2010) (31) have Suggested that Cronbach's alpha is a test for a survey's internal consistency and finding scales are reliable. Values range of Cronbach's alpha is from 0 to 1 . Higher values indicate higher average correlation among the 26 terms. In general, at least 0.7 Cronbach alpha values is good enough. In this case, Figure (1) presents that Cronbach's alpha score is $(0.76)$ which means that questionnaire is reliable to test at any place. 
Figure (3): reliability test (Cronbach's Alpha) results

\begin{tabular}{|c|c|c|c|}
\hline \multicolumn{4}{|c|}{ Case Processing Summary } \\
\hline & & $\mathrm{N}$ & $\%$ \\
\hline \multirow[t]{3}{*}{ Cases } & Valid & 168 & 94.4 \\
\hline & Excludeda $^{a}$ & 10 & 5.6 \\
\hline & Total & 178 & 100.0 \\
\hline
\end{tabular}

a. Listwise deletion based on all variables in the procedure.

\begin{tabular}{|r|r|r|}
\hline \multicolumn{3}{|c|}{ Reliability Statistics } \\
\hline & $\begin{array}{c}\text { Cronbach's Alpha } \\
\text { Based on } \\
\text { Crandardized } \\
\text { Items }\end{array}$ & N of Items \\
\hline .764 & .762 & \\
\hline
\end{tabular}

\section{Data Analysis and Interpretation:}

In the chapter of empirical study, the results of respondents' profile data are presented which are collected from178 questionnaires. Each item in Part I and Part II of the questionnaire is presented using percentages figures and tables. SPSS is used for the simple descriptive data, which describes the mean score of factors.

In order to determine the factors which affect the choice of the bank, the answers reflect in a way of ranking the importance of different factors. Since there are many influencing factors in this study, after collecting the answers from questionnaires, the researcher conducts the advanced statistical procedures of factor analysis. It is a data summarization and reduction technique---

"Exploratory factor analysis", this method can find out the similarity among each factor items

GJEBA: http://escipub.com/global-journal-of-economics-and-business-administration/ in a straightforward way, hence each factor represents a basic property. Even though questions are formulated in a similar way, readers can distinguish these variables. So that factor analysis method is suitable for research about determinant factors of persons in Saudi Arabia for choosing their bank.

Pallant (2010 ( (31)suggest that there are three steps in conducting factor analysis. The process of analysis is presented as follow:

\section{KMO and Bartlett's Test}

$\mathrm{KMO}$ and Bartlett's Test is employed to examine whether the data set of the questionnaire is appropriate for factor analysis.

\section{Factor extraction and rotation}

Factor extraction and rotation are techniques which are used to reduce the large number of Variables so as to determine the number of factors.

\section{Factor interpretation}

According to the result of factor extraction and rotation, each factor would be named Depending on understanding the content of variables. Mean value of factors will be calculated and ranked in order of importance. Moreover, by comparing mean value of different group of respondents, we test whether there are differences among Islamic banks 'customer and their counter parts conventional' customers. So that to find out the character of Saudi people in choosing banks in Tabuk., and give further suggestions for Islamic banks to attract and retain their customers.

\section{Empirical Study}

This chapter consists of two sections. Firstly, the descriptive analysis of customers is Conducted regarding general information of respondents and respondents banking behavior.

The second section presents the respondent's bank selection criteria as well as the mean scores of each item.

\section{Descriptive Analysis:}


Table (3) shows Customers Profile

\begin{tabular}{|c|c|c|c|c|c|c|}
\hline Profile variables & Classification & $\begin{array}{c}\text { Conventional } \\
\text { bank' customer }\end{array}$ & $\begin{array}{l}\text { Islamic bank } \\
\text { customer }\end{array}$ & $\begin{array}{l}\text { Islamic window } \\
\text { 'customer }\end{array}$ & Total & $\%$ \\
\hline \multirow[t]{4}{*}{ Gender } & Male & 1 & 37 & 38 & 76 & $43 \%$ \\
\hline & Female & 9 & 45 & 48 & 102 & $57 \%$ \\
\hline & Total & 10 & 82 & 86 & 178 & 100 \\
\hline & $\%$ & $6 \%$ & $46 \%$ & $48 \%$ & $100 \%$ & \\
\hline \multirow[t]{7}{*}{ Age } & $\begin{array}{l}\text { Less than } 20 \\
\text { years }\end{array}$ & 1 & 2 & 0 & 3 & $2 \%$ \\
\hline & $20-30$ & 3 & 35 & 31 & 69 & $39 \%$ \\
\hline & $31-40$ & 5 & 29 & 33 & 67 & $38 \%$ \\
\hline & $41-50$ & 1 & 10 & 13 & 24 & $13 \%$ \\
\hline & More than 50 & 0 & 6 & 9 & 15 & $8 \%$ \\
\hline & Total & 10 & 82 & 86 & 178 & $100 \%$ \\
\hline & $\%$ & $6 \%$ & $46 \%$ & $48 \%$ & $100 \%$ & \\
\hline \multirow[t]{4}{*}{ Nationality } & Saudi & 6 & 75 & 70 & 151 & $85 \%$ \\
\hline & $\begin{array}{l}\text { Non Saudi } \\
\text { (Moqeem) }\end{array}$ & 4 & 7 & 16 & 27 & $15 \%$ \\
\hline & Total & 10 & 82 & 86 & 178 & $100 \%$ \\
\hline & $\%$ & $6 \%$ & $46 \%$ & $48 \%$ & $100 \%$ & \\
\hline \multirow[t]{4}{*}{ Religious } & Muslim & 10 & 82 & 85 & 177 & $99.4 \%$ \\
\hline & Non-Muslim & 0 & 0 & 1 & 1 & $0.56 \%$ \\
\hline & Total & 10 & 82 & 86 & 178 & \\
\hline & $\%$ & $6 \%$ & $46 \%$ & $48 \%$ & $100 \%$ & \\
\hline \multirow[t]{7}{*}{ Education level } & Uneducated & 0 & 2 & 1 & 3 & $2 \%$ \\
\hline & Primary & 1 & 1 & 8 & 10 & $6 \%$ \\
\hline & Secondary & 0 & 13 & 20 & 33 & $19 \%$ \\
\hline & University & 4 & 50 & 43 & 97 & $54 \%$ \\
\hline & Graduate & 5 & 16 & 14 & 35 & $20 \%$ \\
\hline & Total & 10 & 82 & 86 & 178 & $100 \%$ \\
\hline & $\%$ & $6 \%$ & $46 \%$ & $48 \%$ & $100 \%$ & \\
\hline \multirow[t]{4}{*}{ Job type } & Free workers & 3 & 9 & 9 & 21 & $12 \%$ \\
\hline & House wife & 0 & 8 & 9 & 17 & $10 \%$ \\
\hline & employee & 7 & 65 & 67 & 139 & $78 \%$ \\
\hline & investor & 0 & 0 & 1 & 1 & $1 \%$ \\
\hline
\end{tabular}


According to table (3) observations should be noted $43 \%$ of respondents are male as compare to female $56 \%$ (female number exceed male number ); most of respondents are adult ,because their ages are range from 20-50 (90\%) as compare to younger (less than 20 years) only $2 \%$,and older (more than 50 years ) only $8 \%$.that is means respondent are well understand what they are say . most of the sample respondents are Saudi (85\%) as compare to non-Saudi only $15 \%$. Thus, means that the results of this research represent Saudi opinion. Most of respondents are Muslims $(99.4 \%)$ as compare to non- Muslim only $0.56 \%)$. that is means even Muslim people in Saudi Arabia can choose conventional bank based on service quality and satisfaction. Most of the sample respondents are employees (78\%) the result of this study can be applied to employee market segment in the banking markets.

According to result showing in table (4) we can conclude service quality is the most important factor for choosing a bank service in Saudi Arabia specially Tabuk city. However, cost of service is an important issue of some communities, it represents less important factor for bank selection decision in Saudi community. Thus, the suggestion for Saudi banks should focus in quality of service and make good marketing strategy to attracting institutions to further encourage their employees to purchase banking service.

Moreover, the researcher makes a descriptive analysis for all factors axis's statement:

Table (5), (6), (7), ,(8 ) ,(9)show the result

Table (4) shows Determinants of bank selection ranking according respondents 'answer

\begin{tabular}{|c|c|c|c|}
\hline Reason for bank selection decision & Frequency & Percentage & Ranking \\
\hline Quality of services & 87 & $49 \%$ & 1 \\
\hline The bank of my Affiliation & 35 & $20 \%$ & 2 \\
\hline Geographic location & 27 & 15.2 & 4 \\
\hline Personal relation & 15 & 8.4 & 5 \\
\hline Low cost services & 14 & 7.9 & 3 \\
\hline
\end{tabular}

Source: researcher from data analysis

Table (5) shows Importance ranking of satisfaction axis statements:

\begin{tabular}{|l|l|l|l|l|l|l|l|l|}
\hline Statement & $\mathrm{N}$ & Chi-Square & $\begin{array}{l}\text { Degree of } \\
\text { freedom (df) }\end{array}$ & $\begin{array}{l}\text { Asymp. } \\
\text { Sig. }\end{array}$ & Mean & $\begin{array}{l}\text { Importance } \\
\text { rank }\end{array}$ & $\begin{array}{l}\text { Std. } \\
\text { Error }\end{array}$ \\
\hline $\begin{array}{l}\text { I can pay my purchase electronically } \\
\text { through electronic methods of payment }\end{array}$ & 178 & $97.326 \mathrm{a}$ & 3 & 0000 & 4.28 & 1 & 0.77 \\
\hline $\begin{array}{l}\text { the bank provides me with all banking } \\
\text { services which I need }\end{array}$ & 178 & $100.966^{\mathrm{a}}$ & 3 & 0000 & 4.19 & 2 & & 0.75 \\
\hline $\begin{array}{l}\text { I can contact the bank electronically } \\
\text { from any place in the Saudi Arabia or } \\
\text { out side }\end{array}$ & 178 & $114.584 \mathrm{~b}$ & 4 & 0000 & 3.99 & 3 & 0.92 \\
\hline $\begin{array}{l}\text { the bank provides me with all financial } \\
\text { services when I need it }\end{array}$ & 178 & $107.000 \mathrm{~b}$ & 4 & 0000 & 3.96 & 4 & 0.90 \\
\hline $\begin{array}{l}\text { I can easily contact the bank daily any } \\
\text { time through the day }\end{array}$ & 178 & $93.404 \mathrm{~b}$ & 4 & 0000 & 3.95 & 5 & 0.96 \\
\hline $\begin{array}{l}\text { I completely satisfied from bank } \\
\text { services }\end{array}$ & 178 & $110.034 \mathrm{~b}$ & 4 & 0000 & 3.93 & 6 & 0.95 \\
\hline
\end{tabular}

a. 0 cells $(0.0 \%)$ have expected frequencies less than 5 . The minimum expected cell frequency is 44.5.

b. 0 cells $(0.0 \%)$ have expected frequencies less than 5 . The minimum expected cell frequency is 35.6 .

Source: researcher from data analysis

GJEBA: http://escipub.com/global-journal-of-economics-and-business-administration/ 
Table (6) shows of service quality Importance ranking axis statements:

\begin{tabular}{|c|c|c|c|c|c|c|c|}
\hline Statement & $\mathrm{N}$ & $\begin{array}{l}\text { Chi- } \\
\text { Square }\end{array}$ & $\begin{array}{l}\text { Degree of } \\
\text { freedom } \\
\text { (df) }\end{array}$ & $\begin{array}{l}\text { Asymp. } \\
\text { Sig. }\end{array}$ & Mean & $\begin{array}{l}\text { Importance } \\
\text { rank }\end{array}$ & Std. Error \\
\hline $\begin{array}{l}\text { employees do not Boring from your } \\
\text { enquiries }\end{array}$ & 178 & $131.382^{a}$ & 4 & 0000 & 4.15 & 1 & 0.89 \\
\hline $\begin{array}{l}\text { an employee explains the required service } \\
\text { procedures }\end{array}$ & 178 & $87.281 a$ & 4 & 0000 & 3.85 & 2 & 0.96 \\
\hline $\begin{array}{l}\text { there is enough number of employees to } \\
\text { provide bank 'services for large number } \\
\text { of clients }\end{array}$ & 178 & $61.831^{a}$ & 4 & 0000 & 3.62 & 3 & 1.1 \\
\hline You get the service at relevant time & 178 & $68.742^{\mathrm{a}}$ & 4 & 0000 & 3.54 & 4 & 1.1 \\
\hline $\begin{array}{l}\text { You don't wait for long time in the bank to } \\
\text { get banking service }\end{array}$ & 178 & $21.719^{a}$ & 4 & 0000 & 3.4 & 5 & 1.27 \\
\hline
\end{tabular}

a. 0 cells $(0.0 \%)$ have expected frequencies less than 5 . The minimum expected cell frequency is 35.6. Source: researcher from data analysis

Table (7) shows Important ranking of services 'cost axis statements

\begin{tabular}{|l|l|l|l|l|l|l|l|}
\hline Statement & $\mathbf{N}$ & $\begin{array}{l}\text { Chi- } \\
\text { Square }\end{array}$ & $\begin{array}{l}\text { Degree of } \\
\text { freedom } \\
\text { (df) }\end{array}$ & $\begin{array}{l}\text { Asymp. } \\
\text { Sig. }\end{array}$ & Mean & $\begin{array}{l}\text { Importance } \\
\text { rank }\end{array}$ & $\begin{array}{l}\text { Std. } \\
\text { Error }\end{array}$ \\
\hline $\begin{array}{l}\text { fees costs of transfer is low \& } \\
\text { suitable }\end{array}$ & 178 & $112.281 \mathrm{a}$ & 4 & 0000 & 3.7 & 1 & 0.92 \\
\hline $\begin{array}{l}\text { interest /profit on business } \\
\text { finance is suitable to me }\end{array}$ & 178 & $84.921 \mathrm{a}$ & 4 & 0000 & 3.66 & 2 & 0.98 \\
\hline $\begin{array}{l}\text { Interest /profits required on credit } \\
\text { cards affordable for me and not } \\
\text { high }\end{array}$ & 178 & $47.843 \mathrm{a}$ & 4 & 0000 & 3.47 & 3 & 1.10 \\
\hline $\begin{array}{l}\text { interest /profit on personal } \\
\text { finance is low and suitable to } \\
\text { me }\end{array}$ & 178 & 48.85 & 4 & 0000 & 3.34 & 4 & 1.13 \\
\hline $\begin{array}{l}\text { interest/profit on real estate } \\
\text { finance suitable to me }\end{array}$ & 178 & $104.640 a$ & 4 & 0000 & 3.33 & 5 & 0.98 \\
\hline
\end{tabular}
Source: researcher from data analysis

Table (8) shows Important ranking of financial intermediate services axis statements

\begin{tabular}{|l|l|l|l|l|l|l|l|}
\hline Statement & $\mathbf{N}$ & Chi-Square & $\begin{array}{l}\text { Degree of } \\
\text { freedom } \\
\text { (df) }\end{array}$ & $\begin{array}{l}\text { Asymp. } \\
\text { Sig. }\end{array}$ & Mean & $\begin{array}{l}\text { Importance } \\
\text { rank }\end{array}$ & $\begin{array}{l}\text { Std. } \\
\text { Error }\end{array}$ \\
\hline $\begin{array}{l}\text { the bank provides intermediary } \\
\text { service in Saudi security market }\end{array}$ & 178 & $152.787 \mathrm{a}$ & 4 & 0000 & 3.47 & 1 & 0.78 \\
\hline $\begin{array}{l}\text { the bank provides portfolio } \\
\text { management service as the agent } \\
\text { of client }\end{array}$ & 178 & $88.337 \mathrm{~b}$ & 4 & 0000 & 3.42 & 2 & 0.76 \\
\hline $\begin{array}{l}\text { the bank provides project feasibility } \\
\text { study to help them in investment } \\
\text { decision }\end{array}$ & 178 & $157.730 \mathrm{a}$ & 4 & 0000 & 3.39 & 3 & 0.78 \\
\hline $\begin{array}{l}\text { The bank provides financial } \\
\text { intermediary services in foreign } \\
\text { security market }\end{array}$ & 178 & $186.382 a$ & 4 & 0000 & 3.36 & 4 & 0.76 \\
\hline $\begin{array}{l}\text { the bank provides investment agent } \\
\text { service to its customers }\end{array}$ & 178 & $\begin{array}{l}190.090 a \\
\text { a. 0 cells (0.0\%) have expected frequencies less than 5. The minimum expected cell frequency is 35.6. } \\
\text { b. 0 cells (0.0\%) have expected frequencies less than 5. The minimum expected cell frequency is 44.5. } \\
\text { c. 0 cells (0.0\%) have expected frequencies less than 5. The minimum expected cell frequency is 33.6. }\end{array}$ & 0.76 \\
\hline
\end{tabular}
Source: researcher from data analysis 
Table (9) shows important ranking of Islamic values axis statements

\begin{tabular}{|c|c|c|c|c|c|c|c|}
\hline Statement & $\mathbf{N}$ & $\begin{array}{l}\text { Chi- } \\
\text { Square }\end{array}$ & $\begin{array}{l}\text { Degree of } \\
\text { freedom } \\
\text { (df) }\end{array}$ & $\begin{array}{l}\text { Asymp. } \\
\text { Sig. }\end{array}$ & Mean & $\begin{array}{l}\text { Importance } \\
\text { rank }\end{array}$ & $\begin{array}{l}\text { Std. } \\
\text { Error }\end{array}$ \\
\hline $\begin{array}{l}\text { I don't request any banking service } \\
\text { unless insuring that it's completely } \\
\text { consistent with Sharia'h compliance }\end{array}$ & 178 & $94.798 a$ & 4 & 0000 & 3.96 & 1 & 0.93 \\
\hline $\begin{array}{l}\text { I know that there is valid shariah oversight } \\
\text { body }\end{array}$ & 168 & $81.702 a$ & 4 & 0000 & 3.69 & 2 & 0.95 \\
\hline $\begin{array}{l}\text { the bank's activities are complying with } \\
\text { shariah provision }\end{array}$ & 168 & $76.286 a$ & 4 & 0000 & 3.67 & 3 & 0.96 \\
\hline $\begin{array}{l}\text { Staffs explain banking services procedures } \\
\text { and their compatibility with the provisions of } \\
\text { Islamic sharia }\end{array}$ & 168 & $75.631 a$ & 4 & 0000 & 3.64 & 4 & 0.97 \\
\hline $\begin{array}{l}\text { Bank staff are experienced in the field of } \\
\text { Islamic finance }\end{array}$ & 168 & $56.405 a$ & 4 & 0000 & 3.56 & 5 & 1.1 \\
\hline
\end{tabular}

Source: researcher from data analysis

As we notice from table (9) however not important to client to know about specialization field of staff, the most important factor to Islamic banks' customer is trust that the bank provides them banking services consistence with sharia'h compliance, in addition to get information about existence of sharia'h oversight body. Thus, Islamic bank should be concerning these issues in their marketing strategy.

\section{Analysis and Discussion}

In this section, analysis and discussion are presented based on the empirical finding. Firstly, a brief introduction is presented about factor analysis. Secondly, the finding reports described the outcome of factor analysis in three steps. Choice criteria for all Saudi banks 'customers (full fledge Islamic banks, Islamic window banks, and conventional banks) would be ranked in order based on the mean importance of each factor. Finally, the result of factor analysis is discussed linking to previous theories presented in section two.

\section{Exploratory Factor Analysis:}

"Exploratory factor analysis" is a data summarization and reduction technique which is able to investigate relationships among a large number of individual scale items and to reduce to a more manageable number(Pallant, 2010) . Compared with mean-ranking analysis, 'factor' refers to the group of related variables in factor analysis, could improve the quality of the analysis as well as delivering a holistic view of the selection criteria (Pallant, 2010).

\section{Steps in factor analysis}

There are three main steps to conduct factor analysis in SPSS. Details would be explained Below:

\section{1) KMO and Bartlett's Test}

In order to decide whether a particular data set is appropriate for factor analysis, the KaiserMeyer-Olkin (KMO) and Bartlett's Test need to be conducted before factor analysis. According to Pallant (2010) KMO and Bartlett's Test measure of sampling adequacy which identifies the strength of inter-correlations among those items. The KMO index should be above 0.6 and the Bartlett's test of sphericity index should less than 0.05(Sig. <0.05) which suggests the sample of survey is good enough for factor analysis. As Table (5-1) shows, the value of $\mathrm{KMO}$ for all factors items is (.861) and the value of Bartlett's test of sphericity $(0.000)$ indicate that the factor analysis is appropriate. More over researcher conducts $\mathrm{KMO}$ for each factor items see figures (3),(4),(5),(6),(7) show the value of $\mathrm{KMO}$ for each factor is above (0.5) and the value of Bartlett's test of sphericity $(0.000)$ which indicate that the factor analysis is appropriate for each factor of choice criteria . According to Pallant (2010), for a data exploration technique, the number of factors are determined on research background, 
theoretical framework and researchers' the solution cannot be rotated. So that judgment rather than by a hard statistical rule. researcher considers $(K M O)$ is the base for the Therefore, researcher does not make Rotated number of factors determining. then factors are Component Matrix analysis, because Only one ranked based on factors mean. component was extracted from factor 1 . Hence

Figure (3)

\begin{tabular}{|l|l|l|}
\hline KMO and Bartlett's Test & \multicolumn{2}{|l|}{} \\
\hline Kaiser-Meyer-Olkin Measure of Sampling Adequacy. & \multicolumn{2}{l|}{} \\
\hline Bartlett's Test of Sphericity & Approx. Chi-Square & 2200.130 \\
\cline { 2 - 4 } & df & 325 \\
\cline { 2 - 3 } & Sig. & .000 \\
\hline
\end{tabular}

Figure (4) shows KMO and Bartlett's Test for factor (1) satisfaction

\begin{tabular}{|r|r|r|}
\hline & \multicolumn{2}{c|}{ KMO and Bartlett's Test } \\
\hline \multirow{2}{*}{ Kaiser-Meyer-Olkin Measure of Sampling Adequacy. } & .873 \\
\hline Bartlett's Test of Sphericity & Approx. Chi-Square & 383.015 \\
\cline { 2 - 4 } & $\mathrm{df}$ & 15 \\
\cline { 2 - 4 } & Sig. & .000 \\
\hline
\end{tabular}

Figure (5) shows KMO and Bartlett's Test for factor (2) quality

\begin{tabular}{|r|r|r|}
\hline & \multicolumn{2}{c|}{ KMO and Bartlett's Test } \\
\hline \multirow{2}{*}{ Kaiser-Meyer-Olkin Measure of Sampling Adequacy. } & .817 \\
\hline Bartlett's Test of Sphericity & Approx. Chi-Square & 400.721 \\
\cline { 2 - 4 } & $\mathrm{df}$ & 10 \\
\cline { 2 - 4 } & Sig. & .000 \\
\hline
\end{tabular}

Figure (6) KMO and Bartlett's Test for factor (3) cost of services

\begin{tabular}{|r|r|r|}
\hline \multicolumn{2}{|c|}{ KMO and Bartlett's Test } \\
\hline Kaiser-Meyer-Olkin Measure of Sampling Adequacy. & .824 \\
\hline Bartlett's Test of Sphericity & Approx. Chi-Square & 377.349 \\
\cline { 2 - 4 } & $\mathrm{df}$ & 10 \\
\cline { 2 - 4 } & Sig. & .000 \\
\hline
\end{tabular}

Figure (7) shows KMO and Bartlett's Test for factor (4) cost of financial intermediate

\begin{tabular}{|r|r|r|}
\hline & \multicolumn{2}{|c|}{ KMO and Bartlett's Test } \\
\hline & Kaiser-Meyer-Olkin Measure of Sampling Adequacy. & .838 \\
\hline Bartlett's Test of Sphericity & Approx. Chi-Square & dr \\
\cline { 2 - 4 } & Sig. & 302.860 \\
\cline { 2 - 4 } & & .000 \\
\hline
\end{tabular}

GJEBA: http://escipub.com/global-journal-of-economics-and-business-administration/ 
Figure (8) shows KMO and Bartlett's Test for factor (5) Islamic value

\begin{tabular}{|r|r|r|}
\hline \multicolumn{3}{|c|}{ KMO and Bartlett's Test } \\
\hline \multicolumn{2}{|c|}{ Kaiser-Meyer-Olkin Measure of Sampling Adequacy. } \\
\hline Bartlett's Test of Sphericity & Approx. Chi-Square & .786 \\
\cline { 2 - 4 } & df & 329.226 \\
\cline { 2 - 4 } & Sig. & 10 \\
\hline
\end{tabular}

\section{1) Factor extraction method}

Table (10) shows Extraction Method for factor (1) satisfaction

\begin{tabular}{|l|r|r|}
\hline & \multicolumn{2}{|r|}{ Communalities } \\
\hline the bank provide me with all banking services which I need & 1.000 & Extraction \\
\hline I can easily contact the bank daily any time through the day & 1.000 & .621 \\
\hline I can contact the bank electronically from any place in the Saudi Arabia or out side & 1.000 & .636 \\
\hline I completely satisfied from bank 'services & 1.000 & .653 \\
\hline the bank provides me with all financial services when I need it & 1.000 & .623 \\
\hline I can pay my purchase electronically through electronic methods of payment & 1.000 & .340 \\
\hline \multicolumn{1}{|c|}{ Extraction Method: Principal Component Analysis. } \\
\hline
\end{tabular}

Table (11) shows total variance of satisfaction components

\begin{tabular}{|r|r|r|r|r|r|r|}
\hline & \multicolumn{7}{|c|}{ Total Variance Explained } \\
\cline { 2 - 7 } Componen & \multicolumn{7}{|c|}{ Total } & \% of Variance & Cumulative \% & Total & \% of Variance & Cumulative \% \\
\hline 1 & 3.392 & 56.539 & 56.539 & 3.392 & 56.539 & 56.539 \\
\hline 2 & .746 & 12.441 & 68.980 & & & \\
\hline 3 & .589 & 9.811 & 78.791 & & & \\
\hline 4 & .473 & 7.888 & 86.679 & & & \\
\hline 5 & .450 & 7.494 & 94.173 & & & \\
\hline 6 & .350 & 5.827 & 100.000 & \multicolumn{7}{|c|}{ Extraction Method: Principal Component Analysis. } \\
\hline
\end{tabular}

According to table (5-3) the last statement loading less than 0.4 would be omitted (Field, should be omitted because it loads less than 2005)(32). 0.4. Instead of (Field 2005) variable with a

Table (12) shows component of satisfaction matrix

\begin{tabular}{|l|r|}
\hline & Component Matrix \\
\hline & Component \\
\cline { 2 - 2 } & .788 \\
\hline the bank provide me with all banking services which I need & .732 \\
\hline I can easily contact the bank daily any time through the day & .786 \\
\hline I can contact the bank electronically from any place in the Saudi Arabia or out side & .808 \\
\hline I completely satisfied from bank 'services & .789 \\
\hline the bank provides me with all financial services when I need it & .583 \\
\hline I can pay my purchase electronically through electronic methods of payment & \\
\hline
\end{tabular}




\section{Table (13) shows Extraction Method for factor (2) quality}

\begin{tabular}{|l|r|r|}
\hline \multicolumn{2}{|c|}{ Communalities } \\
\hline & Initial & Extraction \\
\hline $\begin{array}{l}\text { there is enough number of employees to provide bank 'services for } \\
\text { large number of clients }\end{array}$ & 1.000 & .652 \\
\hline you don't wait for long time in the bank to get banking service & 1.000 & 1.000 \\
\hline You get the service at relevant time & 1.000 & .752 \\
\hline an employee explains the required service procedures & 1.000 & .716 \\
\hline employees do not Boring from your enquiries & .481 \\
\hline
\end{tabular}

According to table (5-5) All items are retained because their factors loadings above 0.4 .

Table (14) shows total variance of factor 2(quality)

\begin{tabular}{|c|c|c|c|c|c|c|}
\hline \multicolumn{7}{|c|}{ Total Variance Explained } \\
\hline \multirow[b]{2}{*}{ Component } & \multicolumn{3}{|c|}{ Initial Eigenvalues } & \multicolumn{3}{|c|}{ Extraction Sums of Squared Loadings } \\
\hline & Total & $\%$ of Variance & Cumulative \% & Total & $\%$ of Variance & Cumulative \% \\
\hline 1 & 3.150 & 63.002 & 63.002 & 3.150 & 63.002 & 63.002 \\
\hline 2 & .786 & 15.727 & 78.729 & & & \\
\hline 3 & .457 & 9.148 & 87.877 & & & \\
\hline 4 & .358 & 7.166 & 95.043 & & & \\
\hline 5 & .248 & 4.957 & 100.000 & & & \\
\hline \multicolumn{7}{|c|}{ Extraction Method: Principal Component Analysis. } \\
\hline
\end{tabular}

Table (15) shows factor 2 (quality) component matrix

\begin{tabular}{|l|r|}
\hline \multicolumn{2}{|c|}{ Component Matrix } \\
\hline & \\
\hline there is enough number of employees to provide bank 'services for large number of clients & \\
\hline you don't wait for long time in the bank to get banking service & .808 \\
\hline You get the service at relevant time & .867 \\
\hline an employee explains the required service procedures & .846 \\
\hline employees do not Boring from your enquiries & .694 \\
\hline & .740 \\
\hline
\end{tabular}


Table(16) shows Extraction Method: for factor 3: cost of services

\begin{tabular}{|l|r|r|}
\hline \multicolumn{2}{|l|}{ Communalities } \\
\hline $\begin{array}{l}\text { Interest /profits required on credit cards affordable for me and not } \\
\text { high }\end{array}$ & 1.000 & Initial \\
\hline Profit / interest on personal finance is low and suitable to me & 1.000 & .708 \\
\hline Interest/profit on real estate finance suitable to me & 1.000 & .626 \\
\hline Interest /profit on business finance is suitable to me & 1.000 & .582 \\
\hline Fees cost of transfer is low \& suitable & 1.000 & .455 \\
\hline Extraction Method: Principal Component Analysis. & & \\
\hline
\end{tabular}

Table (17) shows total variance of factor 3 : cost of services

\begin{tabular}{|c|c|c|c|c|c|c|}
\hline & & & & \multicolumn{3}{|c|}{ Total Variance Explained } \\
\hline \multirow[b]{2}{*}{ Component } & \multirow[b]{2}{*}{ Total } & \multicolumn{2}{|c|}{ Initial Eigenvalues } & \multicolumn{3}{|c|}{ Extraction Sums of Squared Loadings } \\
\hline & & $\%$ of Variance & Cumulative \% & Total & $\%$ of Variance & Cumulative \% \\
\hline 1 & 3.127 & 62.533 & 62.533 & 3.127 & 62.533 & 62.533 \\
\hline 2 & .678 & 13.557 & 76.090 & & & \\
\hline 3 & .553 & 11.054 & 87.144 & & & \\
\hline 4 & .393 & 7.855 & 94.999 & & & \\
\hline 5 & .250 & 5.001 & 100.000 & & & \\
\hline
\end{tabular}

\section{Table (18) shows extraction method for factor (4) financial intermediate}

\begin{tabular}{|l|r|r|}
\hline & Communalities \\
\hline The bank provides intermediary service in Saudi security market & 1.000 & \\
. & 1.000 & .668 \\
\hline $\begin{array}{l}\text { The bank provides financial intermediary services in foreign } \\
\text { security market }\end{array}$ & 1.000 & .634 \\
\hline $\begin{array}{l}\text { the bank provides investment agent service to its customers } \\
\text { the bank provide project feasibility study to help them in } \\
\text { investment decision } \\
\text { the bank provide portfolio management service as the agent of }\end{array}$ & 1.000 & .522 \\
\hline
\end{tabular}


Table (19) shows total variance of factor 4 (financial intermediate )components

\begin{tabular}{|c|c|c|c|c|c|c|}
\hline \multicolumn{7}{|c|}{ Total Variance Explained } \\
\hline \multirow[b]{2}{*}{ Component } & & \multicolumn{2}{|c|}{ Initial Eigenvalues } & \multicolumn{3}{|c|}{ Extraction Sums of Squared Loadings } \\
\hline & Total & $\%$ of Variance & Cumulative \% & Total & $\%$ of Variance & Cumulative \% \\
\hline 1 & 2.990 & 59.798 & 59.798 & 2.990 & 59.798 & 59.798 \\
\hline 2 & .648 & 12.958 & 72.756 & & & \\
\hline 3 & .520 & 10.400 & 83.155 & & & \\
\hline 4 & .469 & 9.384 & 92.540 & & & \\
\hline 5 & .373 & 7.460 & 100.000 & & & \\
\hline \multicolumn{7}{|c|}{ Extraction Method: Principal Component Analysis } \\
\hline
\end{tabular}

Table (20) shows component matrix of factor 4 (Financial intermediate

\begin{tabular}{|c|c|}
\hline & Component Matrix ${ }^{a}$ \\
\hline \multirow{3}{*}{ The bank provides intermediary service in Saudi security market } & Component \\
\hline & 1 \\
\hline & .817 \\
\hline The bank provides financial intermediary services in foreign security market & .796 \\
\hline the bank provides investment agent service to its customers & .722 \\
\hline the bank provide project feasibility study to help them in investment decision & .786 \\
\hline the bank provide portfolio management service as the agent of client & .740 \\
\hline Extraction Method: Principal Component Analysis. & \\
\hline
\end{tabular}

Table (21) shows extraction method for factor (5) Islamic value

\begin{tabular}{|l|r|r|}
\hline \multicolumn{2}{|c|}{ Communalities } \\
\hline & Initial & Extraction \\
\hline the bank's activities are comply with shariah provision & 1.000 & .585 \\
\hline I know that there is valid shariah oversight body & 1.000 \\
\hline $\begin{array}{l}\text { I don't request any banking service unless insuring that it's completely consistent with } \\
\text { Sharia'h compliance }\end{array}$ & 1.000 \\
\hline $\begin{array}{l}\text { Staffs explain banking services procedures and their compatibility with the provisions of } \\
\text { Islamic sharia }\end{array}$ & 1.000 \\
\hline Bank staff are experienced in the field of Islamic finance & .618 \\
\hline \begin{tabular}{l} 
Extraction Method: Principal Component Analysis. \\
\hline
\end{tabular} & 1.000 & .392 \\
\hline
\end{tabular}

GJEBA: http://escipub.com/global-journal-of-economics-and-business-administration/ 
Table (22) shows total variance of Islamic value factor

\begin{tabular}{|c|c|c|c|c|c|c|}
\hline \multicolumn{7}{|c|}{ Total Variance Explained } \\
\hline \multirow[b]{2}{*}{ Component } & \multicolumn{3}{|c|}{ Initial Eigenvalues } & \multicolumn{3}{|c|}{ Extraction Sums of Squared Loadings } \\
\hline & Total & $\%$ of Variance & Cumulative \% & Total & $\%$ of Variance & Cumulative \% \\
\hline 1 & 3.013 & 60.253 & 60.253 & 3.013 & 60.253 & 60.253 \\
\hline 2 & .708 & 14.151 & 74.404 & & & \\
\hline 3 & .597 & 11.937 & 86.341 & & & \\
\hline 4 & .443 & 8.866 & 95.208 & & & \\
\hline 5 & 240 & 4.792 & 100.000 & & & \\
\hline Extraction $\mathrm{M}$ & Vlethoc & al Component & ysis. & & & \\
\hline
\end{tabular}

Table (23) shows component matrix of factor (5) Islamic value

\begin{tabular}{|l|r|}
\hline \multicolumn{2}{|c|}{ Component Matrix } \\
\hline the bank's service are comply with shariah provision & \\
\hline I know that there is valid shariah oversight body & .765 \\
\hline $\begin{array}{l}\text { I don't request any banking service unless insuring that it's completely consistent with } \\
\text { Sharia'h compliance }\end{array}$ & .786 \\
\hline $\begin{array}{l}\text { Staffs explain banking services procedures and their compatibility with the provisions of Islamic } \\
\text { sharia }\end{array}$ & .626 \\
\hline Bank staff are experienced in the field of Islamic finance & .858 \\
\hline Extraction Method: Principal Component Analysis. & .825 \\
\hline
\end{tabular}

Factor interpretation:

Basing on step two, five factors are

identified. All items are retained because of the

GJEBA: http://escipub.com/global-journal-of-economics-and-business-administration/ 
factor loadings above 0.4. Except only one item of factor one (satisfaction) is omitted because it load less than 0.4 see table (10). Moreover, mean score of every variable is computed in order to identify the importance of variables to customers in the bank selection process. However, SPSS would not label and interpret each of the factors, so four factors need to be named depending on understanding of the content of variables (Pallant, 2010).

The first factor in Table (24) is satisfaction which includes (offering all banking \&financial service; easy to contact the bank; meet any expected of banking service needs). This factor accounts for 56.5 of the total variance. This factor can be labeled satisfaction, in particular it should be noticed that provide all banking services(mean $=4.19$ ), and availability of electronic contact /or( E, Banking) (mean = 3.99), have the highest mean in this factor, in other word, the vast importance of offering all banking services \& availability of E. Banking determining customer bank selection in Saudi Arabia .

The second factor has been labeled: services quality, which identifies a dimension based on extract service provided by bank, which includes Empathy: employees do not Boring from customers' enquiries (mean $=4.15$ ), Giving personal attention to customers: employees explains the required service procedures (mean $=3.85$ ). This factor accounts for $63.002 \%$ of the total variance.

The third factor is labeled "cost of services" which includes fees of transfer, interest /profit on business finance, interest/profit on credit card, interest /profit on personal finance, interest /profit on real estate finance. This factor accounts for $62.533 \%$ of the total variance. It should be noticed that interest on real estate finance and interest on personal finance is the least important factors, but the vast importance of cost of transfer, and interest on business finance determining customer bank selection in Saudi Arabia. Therefore it indicates that Saudi Arabia is belonging to transfers countries.
The fourth factor is labeled financial intermediate which includes: providing intermediary service in Saudi security market, portfolio management service as the agent of client, helps customer in investment decision (make feasibility study), providing financial intermediary services in foreign security markets, providing investment agent service to customer. This factor accounts for $59.798 \%$ of the total variance. The most important items in this factor in determining bank customer bank selection, are providing intermediary service in Saudi security market (mean $=3.47$ ), portfolio management service as the agent of client (mean=3.42), however the least important items in this factor is investment agent service as well as among all items (mean=3.29).

Fifth factor is labeled Islamic value :which includes providing services consistent with Sharia'h compliance, availability of sharia'h oversight body, providing services comply with sharia'h provision, employees experience of Islamic financial services \&its compatibility with shareia'h provision, experience of staff in the field of Islamic finance. This facto accounts for $60.253 \%$ of the total variance. It should be note that providing services consistent with Sharia'h compliance (mean $=3.96$ ), and availability of sharia's oversight body(mean $=3.69$ ) are the most important item in determining customer bank selection .

Next part of analysis set out to exam whether banks 'customers constitute a homogeneous group concerning the way they choose the bank. Both Saudi and Non-Saudi bank 'customer, male and Female, Islamic banks 'customers and conventional/mixed banks 'customers would be ranked in order of the mean important of factors.

Table (25) shows that there is not significance difference is found in customer bank selection based on nationality, however from table (26) Islamic value is more important to Saudi than Moqeem ,but quality is more important to moqeem than Saudi. See appendix (31) 
Bakhita Hamdow Gad Elkreem Braima, GJEBA, 2018; 3:15

Table (24) shows Results of factor analysis:

\begin{tabular}{|c|c|c|c|c|c|}
\hline \multicolumn{2}{|r|}{ Factors and Items } & $\begin{array}{l}\text { Factor } \\
\text { loadings }\end{array}$ & Mean & $\%$ of Variance & KOM Value \\
\hline \multicolumn{3}{|c|}{ Factor 1 : Satisfaction } & 4.05 & 56.539 & 0.873 \\
\hline 1 & $\begin{array}{l}\text { the bank provide me with all banking } \\
\text { services which I need }\end{array}$ & .789 & 4.19 & 7.888 & \\
\hline 2 & $\begin{array}{l}\text { I can contact the bank electronically from } \\
\text { any place in the Saudi Arabia or out side }\end{array}$ & .786 & 3.99 & 9.811 & \\
\hline 3 & $\begin{array}{l}\text { the bank provides me with all financial } \\
\text { services when I need it }\end{array}$ & .789 & 3.96 & 7.494 & \\
\hline 4 & $\begin{array}{l}\text { I can easily contact the bank daily any } \\
\text { time through the day }\end{array}$ & .732 & 3.95 & 12.441 & \\
\hline 5 & I completely satisfied from bank 'services & .808 & 3.93 & 7.888 & \\
\hline \multicolumn{3}{|c|}{ Factor 2: services quality } & 3.74 & 63.002 & 0.817 \\
\hline 1 & $\begin{array}{l}\text { employees do not Boring from your } \\
\text { enquiries }\end{array}$ & 0.740 & 4.15 & 4.957 & \\
\hline 2 & $\begin{array}{l}\text { an employee explains the required service } \\
\text { procedures }\end{array}$ & .694 & 3.85 & 7.166 & \\
\hline 3 & $\begin{array}{l}\text { there is enough number of employees to } \\
\text { provide bank 'services for large number of } \\
\text { clients }\end{array}$ & .808 & 3.62 & 63.002 & \\
\hline 4 & I get the service at relevant time & .846 & 3.54 & 9.148 & \\
\hline 5 & $\begin{array}{l}\text { don't wait for long time in the bank to get } \\
\text { banking service }\end{array}$ & .867 & 3.4 & 15.727 & \\
\hline $\begin{array}{l}\text { Factor 3: cost of } \\
\text { services }\end{array}$ & 3.50 & 62.533 & 0.824 & & \\
\hline 1 & Fees cost of transfer is low \& suitable & .675 & 3.7 & 5.001 & \\
\hline 2 & $\begin{array}{c}\text { Interest /profit on business finance is } \\
\text { suitable to me }\end{array}$ & .763 & 3.66 & 7.855 & \\
\hline 3 & $\begin{array}{l}\text { Interest /profits required on credit cards } \\
\text { affordable for me and not high }\end{array}$ & .842 & 3.47 & 62.533 & \\
\hline 4 & $\begin{array}{l}\text { Profit / interest on personal finance is low } \\
\text { and suitable to me }\end{array}$ & .869 & 3.34 & 13.557 & \\
\hline 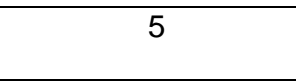 & $\begin{array}{l}\text { Interest/profit on real estate finance suitable } \\
\text { to me }\end{array}$ & .791 & 3.33 & 11.054 & \\
\hline $\begin{array}{l}\text { Factor 4: financial } \\
\text { intermediate }\end{array}$ & 3.39 & 59.798 & 0.838 & & \\
\hline 1 & $\begin{array}{l}\text { the bank provides intermediary service in } \\
\text { Saudi security market }\end{array}$ & .817 & 3.47 & 59.798 & \\
\hline 2 & $\begin{array}{l}\text { the bank provide portfolio management } \\
\text { service as the agent of client }\end{array}$ & .740 & 3.42 & 7.460 & \\
\hline 3 & $\begin{array}{l}\text { the bank provide project feasibility study to } \\
\text { help them in investment decision }\end{array}$ & .786 & 3.39 & 9.384 & \\
\hline 4 & $\begin{array}{l}\text { The bank provides financial intermediary } \\
\text { services in foreign security market }\end{array}$ & .796 & 3.36 & 12.958 & \\
\hline 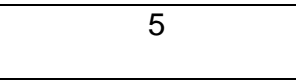 & $\begin{array}{l}\text { the bank provides investment agent service } \\
\text { to its customers }\end{array}$ & .722 & 3.29 & 10.400 & \\
\hline $\begin{array}{l}\text { Factor 5: Islamic } \\
\text { value }\end{array}$ & 3.70 & 60.253 & 0.786 & & \\
\hline 1 & $\begin{array}{l}\text { I don't request any banking service unless } \\
\text { insuring that it's completely consistent with } \\
\text { Sharia'h compliance }\end{array}$ & .626 & 3.96 & 11.937 & \\
\hline 2 & $\begin{array}{l}\text { I know that there is valid shariah oversight } \\
\text { body }\end{array}$ & .786 & 3.69 & 14.151 & \\
\hline 3 & $\begin{array}{l}\text { the bank's service are comply with shariah } \\
\text { provision }\end{array}$ & .765 & 3.67 & 60.253 & \\
\hline 4 & $\begin{array}{l}\text { Staffs explain banking services procedures } \\
\text { and their compatibility with the provisions of } \\
\text { Islamic sharia }\end{array}$ & .858 & 3.64 & 8.866 & \\
\hline 5 & $\begin{array}{l}\text { Bank staff are experienced in the field of } \\
\text { Islamic finance }\end{array}$ & .825 & 3.56 & 4.792 & \\
\hline
\end{tabular}




\begin{tabular}{|c|c|c|c|c|c|c|}
\hline & & Sum of Squares & $d f$ & Mean Square & $F$ & Sig. \\
\hline \multirow[t]{4}{*}{ Satisfaction * nationality } & Between Groups (Combined) & & & & & \\
\hline & & .597 & 1 & .597 & 1.379 & .242 \\
\hline & Within Groups & 76.226 & $176 \mid$ & 433 & & \\
\hline & Total & 76.823 & 177 & & & \\
\hline \multirow[t]{4}{*}{ quality * nationality } & Between Groups (Combined) & & & & & \\
\hline & & .056 & 1 & .056 & .076 & .784 \\
\hline & Within Groups & 131.131 & 176. & .745 & & \\
\hline & Total & 131.188 & 177 & & & \\
\hline \multirow[t]{4}{*}{ cost of banking services * nationality } & Between Groups (Combined) & & & & & \\
\hline & & .018 & 1 & .018 & .027 & .870 \\
\hline & Within Groups & 116.321 & $176 \mid$. & .661 & & \\
\hline & Total & 116.339 & 177 & & & \\
\hline \multirow[t]{4}{*}{ financial intermediat * nationality } & Between Groups (Combined) & & & & & \\
\hline & & 663 & 1 & .663 & 1.898 & .170 \\
\hline & Within Groups & 61.475 & $176 \mid$. & 349 & & \\
\hline & Total & 62.138 & 177 & & & \\
\hline \multirow[t]{4}{*}{ Islamic values * nationality } & Between Groups (Combined) & & & & & \\
\hline & & 375 & 1 & .375 & 647 & 422 \\
\hline & Within Groups & 96.343 & $166 \mid$. & .580 & & \\
\hline & Total & 96.718 & 167 & & & \\
\hline
\end{tabular}

Table (26) shows importance ranking for the factors based on nationality

\begin{tabular}{|l|l|l|l|l|l|}
\hline & Satisfaction & quality & $\begin{array}{l}\text { cost of banking } \\
\text { services }\end{array}$ & $\begin{array}{l}\text { financial } \\
\text { intermediate }\end{array}$ & \\
\hline rank & & & & & \\
\hline Saudi & 1 & 3 & 4 & 5 & 2 \\
\hline $\begin{array}{l}\text { Soqeem(non- } \\
\text { Saudi) }\end{array}$ & 1 & 2 & 4 & 5 & 3 \\
\hline
\end{tabular}


Table (27) shows ANOVA test result of difference based on gender:

ANOVA Table

\begin{tabular}{|c|c|c|c|c|c|c|c|}
\hline & & & $\begin{array}{l}\text { Sum } \\
\text { Squares }\end{array}$ & df & Mean Square & $F$ & Sig. \\
\hline \multirow{3}{*}{$\begin{array}{l}\text { Satisfaction } \\
\text { gender }\end{array}$} & *Between Groups & (Combined) & .032 & 1 & .032 & .073 & .788 \\
\hline & Within Groups & & 76.791 & 176 & .436 & & \\
\hline & Total & & 76.823 & 177 & & & \\
\hline \multirow{3}{*}{$\begin{array}{l}\text { quality } \\
\text { gender }\end{array}$} & *Between Groups & (Combined) & .876 & 1 & .876 & 1.183 & 278 \\
\hline & Within Groups & & 130.312 & 176 & .740 & & \\
\hline & Total & & 131.188 & 177 & & & \\
\hline \multirow{3}{*}{$\begin{array}{l}\text { cost of banking } \\
\text { services } \\
\text { gender }\end{array}$} & gBetween Groups & (Combined) & 1.766 & 1 & 1.766 & 2.713 & .101 \\
\hline & Within Groups & & 114.573 & 176 & .651 & & \\
\hline & Total & & 116.339 & 177 & & & \\
\hline \multirow{3}{*}{$\begin{array}{l}\text { financial } \\
\text { intermediat } \\
\text { gender }\end{array}$} & $\begin{array}{l}\text { Between Groups } \\
\text { * }\end{array}$ & (Combined) & .517 & 1 & .517 & 1.477 & 226 \\
\hline & Within Groups & & 61.620 & 176 & .350 & & \\
\hline & Total & & 62.138 & 177 & & & \\
\hline \multirow{3}{*}{$\begin{array}{l}\text { Islamic values } \\
\text { gender }\end{array}$} & *Between Groups & (Combined) & .570 & 1 & .570 & .984 & 323 \\
\hline & Within Groups & & 96.148 & 166 & .579 & & \\
\hline & Total & & 96.718 & 167 & & & \\
\hline
\end{tabular}

According to table (27) Although, there is no male than female, in contrast, Islamic value is significant difference in bank choice is noted more important to female than male see table base on gender, quality is more important to (28) .see appendix (32)

Table (28) shows importance of factors ranking based on gender

\begin{tabular}{|l|l|l|l|l|l|}
\hline & Satisfaction & quality & $\begin{array}{l}\text { cost of banking } \\
\text { services }\end{array}$ & $\begin{array}{l}\text { financial } \\
\text { intermediate }\end{array}$ \\
\hline rank & & & & & \\
\hline male & 1 & 2 & 4 & 5 & 3 \\
\hline female & 1 & 3 & 4 & 5 & 2 \\
\hline
\end{tabular}


Table (29) shows ANOVA test result of difference based on type of bank:

\section{ANOVA Table}

\begin{tabular}{|c|c|c|c|c|c|c|}
\hline & & $\begin{array}{l}\text { Sum } \\
\text { Squares }\end{array}$ & df & $\begin{array}{l}\text { Mean } \\
\text { Square }\end{array}$ & $F$ & Sig. \\
\hline \multirow{2}{*}{\multicolumn{2}{|c|}{$\begin{array}{l}\text { Satisfaction * what is theBetween Groups } \\
\text { type of the bank where you } \\
\text { have opened your account? Within Groups }\end{array}$}} & 1.557 & 2 & .779 & 1.810 & .167 \\
\hline & & 75.266 & 175 & .430 & & \\
\hline Total & & 76.823 & 177 & & & \\
\hline \multirow{2}{*}{\multicolumn{2}{|c|}{$\begin{array}{l}\text { Quality * what is the type ofBetween Groups } \\
\text { the bank where you have- } \\
\text { opened your account? }\end{array}$}} & .506 & 2 & .253 & .339 & .713 \\
\hline & & 130.681 & 175 & .747 & & \\
\hline Total & & 131.188 & 177 & & & \\
\hline \multirow{2}{*}{\multicolumn{2}{|c|}{$\begin{array}{l}\text { Cost of banking services }{ }^{*} \text { Between Groups } \\
\text { what is the type of the bank } \\
\text { where you have opened yourWithin Groups } \\
\text { account? }\end{array}$}} & 2.593 & 2 & 1.297 & 1.995 & .139 \\
\hline & & 113.746 & 175 & .650 & & \\
\hline \multicolumn{2}{|l|}{ Total } & 116.339 & 177 & & & \\
\hline \multirow{2}{*}{\multicolumn{2}{|c|}{$\begin{array}{l}\text { Financial intermediate * what isBetween Groups } \\
\text { the type of the bank where you } \\
\text { have opened your account? Within Groups }\end{array}$}} & 1.141 & 2 & .571 & 1.637 & .198 \\
\hline & & 60.996 & 175 & 349 & & \\
\hline \multicolumn{2}{|l|}{ Total } & 62.138 & 177 & & & \\
\hline \multirow{2}{*}{\multicolumn{2}{|c|}{$\begin{array}{l}\text { Islamic values * what is theBetween Groups } \\
\text { type of the bank where you } \\
\text { have opened your account? Within Groups }\end{array}$}} & 1.310 & 2 & .655 & 1.132 & .325 \\
\hline & & 95.408 & 165 & .578 & & \\
\hline Total & & 96.718 & 167 & & & \\
\hline
\end{tabular}

According to table (29) there is no significant their counter part (conventional/mixed) difference in bank choice is noted base on type 'customers, in contrast, service quality is more of bank (full fledge Islamic bank /or not) important for conventional and semi Islamic ,however Islamic value is more important factor banks 'customers than full fledge Islamic banks for Full fledge Islamic banks ' customer than 'customers. see appendix (33)

Table (30 shows importance of factors ranking based on bank type

\begin{tabular}{|l|l|l|l|l|l|}
\hline & Satisfaction & quality & $\begin{array}{l}\text { cost of banking } \\
\text { services }\end{array}$ & $\begin{array}{l}\text { financial } \\
\text { intermediate }\end{array}$ & Islamic values \\
\hline rank & & & & & \\
\hline conventional & 1 & 2 & 4 & 5 & 3 \\
\hline full fledge Islamic bank & 1 & 3 & 4 & 5 & 2 \\
\hline Islamic window bank(mixed) & 1 & 2 & 4 & 5 & 3 \\
\hline
\end{tabular}




\section{Discussion:}

Table (4) shows that the most important factor affect customer decision in select a bank to open his/she is account is quality factor .this result goes consistent with Dr. Gazie S. Okpara(2013) he stated that service quality is most influential of all the six determinant-factors (which include Proximity, attractiveness, referrals, marketing and price followed suit, and quality of services) for the choice of commercial banks. Also this result goes consistent with Muhamad Jantan,(july 1998), Irfan Ahmed, (May 2012, Aregbeyen,( December 2011).

Table (5 ) shows that electronic methods of payment is most important item in the satisfaction factor (mean $=4.28$ ) as well as all 26 items in all five factors, however this item is excluded from the factor in extraction method step see table (10) it loads less than 0.4 . This indicate that electronic methods of payment does not belong to satisfaction factor, it can be belong to service quality, because it loads 4.11 of variance within factor 'items see Tables (31), (32).

Also from table (5) and (10) it should be noted that the most important item of satisfaction factor is availability of all banking services (mean $=4.19$ ), followed by adaption of modern electronic telecommunication facilities (mean =3.99). This result goes consistent with, Omo Aregbeyen,(December 2011) he had demonstrated that safety of funds and the availability of technology based service(s) are the major reasons for customers' choice of banks.

Table (31) Total Variance Explained

\begin{tabular}{|l|l|l|l|l|l|l|}
\hline \multirow{2}{*}{ Component } & \multicolumn{3}{|l|}{ Initial Eigenvalues } & \multicolumn{3}{l|}{ Extraction Sums of Squared Loadings } \\
\cline { 2 - 7 } & Total & $\%$ of Variance & Cumulative \% & Total & $\%$ of Variance & Cumulative \% \\
\hline 1 & 3.308 & 55.135 & 55.135 & 3.308 & 55.135 & 55.135 \\
2 & 1.004 & 16.742 & 71.877 & 1.004 & 16.742 & 71.877 \\
3 & 640 & 10.670 & 82.547 & & & \\
4 & 447 & 7.453 & 90.000 & & & \\
5 & 353 & 5.886 & 95.886 & & & \\
6 & 247 & 4.114 & 100.000 & & & \\
\hline
\end{tabular}

Extraction Method: Principal Component Analysis.

Table (32)

\begin{tabular}{|c|c|c|}
\hline \multicolumn{3}{|l|}{ Communalities } \\
\hline & Initial & Extraction \\
\hline $\begin{array}{l}\text { there is enough number of employees to provide bank 'services for a large number of } \\
\text { clients }\end{array}$ & 1.000 & .778 \\
\hline I don't wait for long time in the bank to get banking service & 1.000 & .825 \\
\hline I get the service at relevant time & 1.000 & .731 \\
\hline an employee explain the required service procedures & 1.000 & .566 \\
\hline employees do not boring from my enquiries & 1.000 & .654 \\
\hline I can pay my purchase electronically through electronic methods of payment & 1.000 & .758 \\
\hline
\end{tabular}


Table (6) shows the most important item of service quality factor is the Empathy: employees do not Boring from customers 'enquiries (mean =4.15), in addition to an employee explains the required service procedures (mean $=3.85$ ). based on Descending order. This result goes consistent with (Parasuraman, 1988) model. Moreover it adds new rank of service quality items; this result reveals that Empathy is the most important element of service quality items.

Table (7) shows Important ranking of services 'cost axis statements in descending order includes: fees costs of transfer (mean=3.7), interest /profit on business finance (mean=3.66), Interest /profits required on credit cards (mean=3.47), interest /profit on personal finance (mean=3.34). interest/profit on real estate finance $($ mean $=3.33)$.it should be noted that fees costs of transfer is the most important item of service cost factor in determining customer 'bank choice . thus it indicates that Saudi Arabia is one of transfers countries .

Table (8) shows importance rank of financial intermediate items in descending order: providing intermediary service in Saudi security market (mean=3.47), providing portfolio management service as the agent of client (mean =3.42), help customer in investment decision (mean =3.39), providing financial intermediary services in foreign security market (mean =3.36), providing investment agent service to its customers (mean=3.29). Thus providing investment agent service to its customers is least important item in financial intermediate factor, as well as all as of all five factors 'items ( 26 items).

${ }^{*}$ This result bridges the gap because there is no clear consensus about the effect of financial intermediate factor in customer bank selection criteria.

Table (9) shows important ranking of Islamic values axis items, in descending order including: assurance of providing banking services consistence with sharia'h compliance(mean=3.96), availability of valid of bank (full fledge Islamic bank /or not), GJEBA: http://escipub.com/global-journal-of-economics-and-business-administration/ shariah oversight body (mean=3.69), bank should comply with shareia'h compliance in its activities(mean $=3.67$ ), Staffs explain banking services procedures and their compatibility with the provisions of Islamic sharia $($ mean $=3.64)$, Bank staff are experienced in the field of Islamic finance (mean $=3.56$ ). Thus it should be noted that assurance of providing banking services consistence with sharia'h compliance is the most important item of Islamic value factor in determining customer bank selection . This result goes consistence with Ahmad Azrin Adnan, (2013) they recommended that marketing activities by Islamic banks should consistently comply with the shariah principles.; Also it goes consist Salman Masood (2014) Their results showed that customers use only the current and saving accounts; they do not use different modes of financing because of less awareness about the products and financing modes of Islamic banks.

Table (24) shows Results of factor analysis, it should be conclude that rank of studies factor which are effect on customers decision in choose their banks in descending order : Satisfaction (mean=4.05), services quality (mean=3.74), Islamic value (mean=3.7), cost of services(mean=3.5), financial intermediate(mean=3.39).

Table (25) shows that there is not significance difference is found in customer bank selection based on nationality, however from table (26) Islamic value is more important to Saudi than Moqeem ,but quality is more important to moqeem than Saudi. This considers is new result because there is no previous work revealing this issue.

According to table (27) Although, there is no significant difference in bank choice is noted base on gender, quality is more important to male than female, in contrast, Islamic value is more important to female than male see table (28) in Saudi Arabia community .

According to table (29) there is no significant difference in bank choice is noted base on type 
however Islamic value is more important factor for Full fledge Islamic banks 'customer than their counter part (conventional/mixed) "customers, in contrast, service quality is more important for conventional and semi Islamic banks 'customers than full fledge Islamic banks 'customers. These results goes consistent with Kabiru\&lbrhim(2014) he had demonstrated that Perception, Awareness and Understanding are positively associated with Muslim account holders in conventional banks toward Islamic banking products. then he recommended that the Islamic banking industry should focus on the people's understanding of Shariah position on business transactions, concept of profit and loss sharing practice, benefit of Islamic banking products, good understanding of Islamic banking theory and practice that would have impact on customer decision. Also the results go consistent with Ahmad and Haron (2002) they have reported that the majority of Islamic bank customers emphasized religious as well as other factors.

\section{Conclusion:}

* Results

1- the most important factor affect customer decision in select a bank to open his/she is account is quality factor

2- electronic methods of payment is most important item affect customer decision in choose a bank, moreover it doesn't belong to satisfaction factor ,but it belong to quality factor

3- the most important item of service quality factor is the Empathy

4- the most important item of service cost factor in determining customer 'bank choice

5- Financial intermediate factor includes: providing intermediary service in local security market, providing portfolio management service as the agent of client, helping customer in investment decision, providing financial intermediary services in foreign security market, providing investment agent service to banks 'customers.
6 - the most important item of financial intermediate factor in customer select a bank service is providing intermediary service in local security market, however the least important item of financial intermediate is, providing investment agent service to banks ' customers, as well as all other factor 'items (26 items)

7- Islamic value factor which effect on customers decision about their bank choice consists of : assurance of providing banking services consistence with sharia'h compliance, availability of valid shariah oversight body, bank should comply with shareia'h compliance in its activities, Staffs explain banking services procedures and their compatibility with the provisions of Islamic sharia, Bank staff are experienced in the field of Islamic finance.

8- Cost of service factor includes fees costs of transfer, interest on business finance. Interest required on credit cards, interest required on personal finance interest required on real estate finance

9- the most important item of Islamic value factor in determining customer 'bank selection ,is assurance of providing banking services consistence with sharia'h compliance

10-Importance rank of studies factor which are effect on customers decision in choose their banks in descending order : Satisfaction(1),services quality(2), Islamic value(3) , cost of services(4), financial intermediate(5).

11-there is not significance difference is found in customer bank selection based on nationality

12-Islamic value is more important to Saudi than Moqeem, but quality is more important to moqeem than Saudi.

13-There is no significant difference in bank choice is noted base on gender.

14-Quality is more important to male than female, in contrast, Islamic value is more important to female than male. 
15-there is no significant difference in bank choice is noted base on type of bank (full fledge Islamic bank /or not)

16-Islamic value is more important factor for Full fledge Islamic banks ' customer than their counter part (conventional/mixed) 'customers

17-Service quality is more important for conventional and semi Islamic banks 'customers than full fledge Islamic banks 'customers.

18-Ranks of factors affect customer decision in select a bank service based on their mean, are satisfaction (mean $=4.05$ ), service quality (mean=3.74), Islamic value (mean $=3.7$ ) service cost (mean=3.5), financial intermediate (mean $=3.39$ ).

\section{* Recommendations}

1- Suggestion for Saudi banks should focus in quality of service, and make good marketing strategy to attracting institutions to further encourage their employees to purchase banking service.
2- Islamic banks should be emphasizing on customers 'trust about services consistent with sharia'h provision.

3- Banks should note that Saudi Arabia is one of transfers' countries. So that to consider this in their marketing strategy.

4- According to above result (10), it can be conclude that the market segment type Saudi banks 'customer is task-oriented bank customer (Kaynak and Holistius (1995.pp:12)

\section{Future research suggestion:}

$\checkmark$ Because the results of this study are only based on customer's perceptions, it could be an interesting research area for future researchers to investigate the correspondence between service providers' and consumers' perceptions.

$\checkmark$ This research follows qualitative approach, therefore, a multi-level research is interesting area will be conduct to test impact of customers' satisfaction on banks 'savings level.

\section{Research frame work:}

\section{Independent factors}

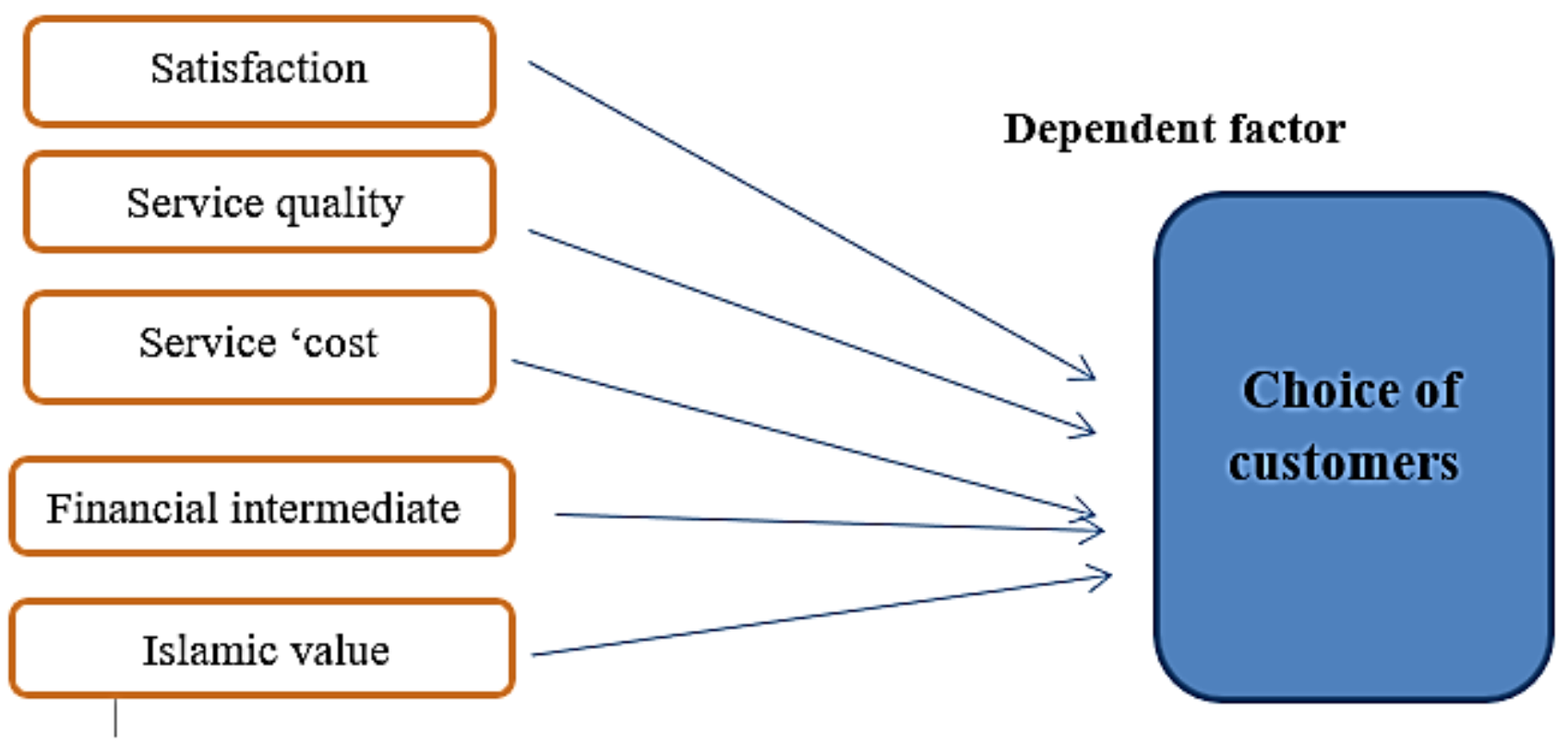

\section{References:}

1. Kaynak E. and Holstius, K. (1995), Retail banking in Nordic countries: the case of Finland,
International Journal Of Bank Marketing, Vol. 13 No. 8 , pp. $10-20$

2. Kaynak, E, and Whiteley, A.(1999), Retail bank marketing in Western Australia, International 
,Journal Of Bank Marketing, Vol. 17 No. 5, pp. 221-232.

3. Kaynak, E, and Kucukemiroglu, O. (1992), Bank and Product Selection Hong Kong", International Journal Of Bank Marketing, Vol. 10 No. 1, pp. 3.

4. Narteh, B, and Owusu-Frimpong, N.(2011), An analysis of students' knowledge and choice criteria in retail bank selection in sub-Saharan Africa : the case of Ghana, The International Journal Of Bank Marketing, Vol. 29 No. 5, pp. 373-397.

5. Frost, F.A. and Kumar, M. (2000), INTSERVQUAL: an internal adaptation of the GAP model in a large service organization, Journal of Services Marketing, Vol. 14 No. 5, pp. 358-77.

6. Philip, G. and Hazlett, S.A. (1997), the measurement of service quality: a new P-C-P attributes model, International Journal of Quality \& Reliability Management, Vol. 14 No. 3, pp. 260-86.

7. Broderick, A.J. and Vachirapornpuk, S. (2002), Service quality in Internet banking: the importance of customer role, Marketing Intelligence \& Planning, Vol.20 No.6, pp. 327335.

8. Parasuraman, A., Zeithaml, V.A. and Berry, L.L. (1985), A conceptual model of service quality and its implication for future research, Journal of Marketing, Vol. 49, pp. 41-50.

9. Parasuraman, A., Zeithaml, V.A. and Berry, L.L. (1988), SERVQUAL: a multiple item scale for measuring consumer perception of service quality, Journal of Retailing, Vol. 64 No. 1, pp.1240

10. Omo Aregbeyen (2011),the determinants of bank selection choices by customer evidence from Nigeria ,international journal of business and social sience,vol2,No,22;Dec 2011 pp:276-288

11. Almossawi,M.(2001). Bank selection criteria employed by college students in Bahrain: empirical analys, International Journal of Bank Marketing, 19/3, 115-125, MCB University Press.

12. Cicic M., Brkic N. and Agic E. (2004). Bank Selection Criteria Employed by Students in a Southeastern European Country: An Empirical Analysis of Potential Market Segments' Preferences; University of Sarajevo

13. Syed, A. M., \& Guruswamy, D. (2007). Customer preferences for retail banking services in Ethiopia: with special reference to retail banks in Mekelle City.

14. Rehman, H.U., \& Saima, A. (2008). An empirical analysis of the determinants of bank selection in Pakistan: A customer view. Pakistan economic and social review, volume 46, No 2.

15. Boyd, W. L., Leonard, M., \& White, C. (1994). Customer preferences for financial services: An analysis. International Journal of Bank Marketing, volume, 12, No. 1.
16. Tilahun Aemiro Tehulu, Gedifew Agalu Wondmagegn ,(2014), Factors Influencing Customers' Bank Selection Decision in Ethiopia: The Case of Bahir Dar City, Research Journal of Finance and Accounting ISSN 2222-1697 (Paper) ISSN 2222-2847 (Online) Vol.5, No.21,pp. 57-68 .

17. Irfan Ahmed, Saira Ashfaq, Shahid Mahmood, Umar Farooq, Determinant Attributes of Customer Choice of Banks, Supplying Mortgage Products , Journal of Economics and Behavioral Studies Vol. 4, No. 5, pp. 287-296, May 2012 (ISSN: 2220-6140

18. Muhamad Jantan ,Abdul Razak Kamaruddin (July1998), customer choice in retail banking A A M Journal ,Vol 3, No2 ,pp.19- 32

19. Gazie S. Okpara \& Onuoha A. Onuoha, (November 2013) , Bank Selection and Patronage By University Students: A Survey of Students in Umudike, Nigeria , Asian Business Review, Volume 2, (Issue 4) ISSN 2304-2613 (Print); ISSN 2305-8730 (Online)

20. Ahmad Azrin Adnan, (2013) ${ }^{1}$ Noor Azeanti Mohd Nasir and Dalfiza Mohd Yusof(2013), Bank Choice Behaviors among Malaysian Muslims: A Qualitative Approach, International Research Journal of Social Sciences, Vol. 3(2),1-8.

21. Kabiru\&lbrhim(2014) , ASSESSING THE INSIGHT OF MUSLIM ACCOUNT HOLDERS' IN CONVENTIONAL BANK TO PURCHASE ISLAMIC BANK PRODUCTS, Journal of Emerging Economies and Islamic Research 2014, Vol 2, No. 3, pp.1-21

22. Ahmad, N., \& Haron, S. (2002). Perceptions of Malaysian corporate customers towards Islamic banking products and services. International Journal of Islamic Financial Services, 3(4), 1329.

23. Dar, Humayon, and Presley John. (September2000)_Lack of Profit Loss Sharing in Islamic Banking: Management and Control Imbalances, International Journal of Islamic Financial Services,vol: 2 .No :2 .pp:1-49

24. Salman Masood1*, Sumaira Rehman2, and Chaudhry Abdul Rehman3, (December 2014 ,Cognizing Customer Awareness and Perception of Islamic Banking Products in Pakistan, International Journal of Operations and Logistics Management -ISSN: 2310-4945; e-ISSN: 2309-8023 Volume: 3, Issue: 4, pp: 322-336

25. Adi Zakaria Afiff * and Rifelly Dewi Astuti(June 2009), The Addition of Spiritual Dimension on Customer Value to Investigate the Relationship of Customer Value, Customer Satisfaction and Behavior Intention on Islamic Banks Saving Products in Indonesia, ASEAN MARKETING JOURNAL June 2009 - Vol.I - No. 1,pp. 13 - 23

26. MURYANI ARSAL1, NIK INTAN NORHAN BT ABDUL HAMID2, ROSFIAH ARSAL3., AND MUHAMMAD BASRI4(2014), CONSUMER 
BEHAVIOR OF THE ISLAMIC BANKING, International Journal of Science Commerce and Humanities ,Volume No 2 No 7 ,p.59-64.

27. Rahmatina A. Kasri and Salina Hj. Kassim(2009) Empirical Determinants of Saving in the Islamic Banks: Evidence from Indonesia, JKAU: Islamic Econ., Vol. 22 No. 2, pp: 181-201 (2009 A.D./1430 A.H.)

28. Agarwal P. K.(Feb.2017), Influencing factors for bank selection intention in Ethiopia: A study conducted in Arba Minch Town, Business and Management Research Journal Vol. 7(2):pp. 10 - 16. ,ISSN: 2026-6804 @2017 International Research Journals .

29. Aleksyeyenko Alina(2010) individual and banks 'characteristics that impact an individuals' demand for services, $A$ thesis submitted in partial fulfillment of the requirements for the degree of MA in Economics Kyiv School of Economics, Ukraine.

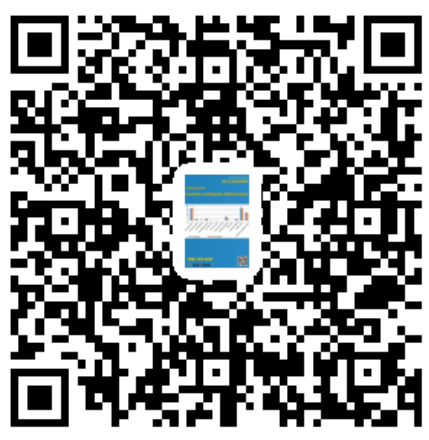

30. Cooper, D. R. and Schindler, P. S. (2003), Business research methods, New York, McGraw-Hill Higher Education.

31. Pallant, J. (2010), SPSS survival manual: A step by step guide to data analysis using SPSS, . Maryborough Victoria, Canberra, Australia, McPherson's Printing Group.

32. Field, A.P. (2005), Factor Analysis Using SPSS, Discovering Statistics using IBM SPSS Statistics, London: Sage, pp.166-204. 